\title{
The $\mathrm{C}_{50}$ carotenoid bacterioruberin regulates membrane fluidity in pink-pigmented Arthrobacter species
}

\author{
Alexander Flegler ${ }^{1}\left[\right.$ (i) $\cdot$ André Lipski ${ }^{1}$ (i)
}

Received: 15 October 2021 / Revised: 23 November 2021 / Accepted: 9 December 2021 / Published online: 24 December 2021

(c) The Author(s) 2021

\begin{abstract}
Carotenoids have several crucial biological functions and are part of the cold adaptation mechanism of some bacteria. Some pink-pigmented Arthrobacter species produce the rare $\mathrm{C}_{50}$ carotenoid bacterioruberin, whose function in these bacteria is unclear and is found mainly in halophilic archaea. Strains Arthrobacter agilis DSM $20550^{\mathrm{T}}$ and Arthrobacter bussei DSM $109896^{\mathrm{T}}$ show an increased bacterioruberin content if growth temperature is reduced from 30 down to $10^{\circ} \mathrm{C}$. In vivo anisotropy measurements with trimethylammonium-diphenylhexatriene showed increased membrane fluidity and a broadening phase transition with increased bacterioruberin content in the membrane at low-temperature growth. Suppression of bacterioruberin synthesis at $10{ }^{\circ} \mathrm{C}$ using sodium chloride confirmed the function of bacterioruberin in modulating membrane fluidity. Increased bacterioruberin content also correlated with increased cell resistance to freeze-thaw stress. These findings confirmed the adaptive function of bacterioruberin for growth at low temperatures for pink-pigmented Arthrobacter species.
\end{abstract}

Keywords Arthrobacter $\cdot$ Bacterioruberin $\cdot$ Carotenoid $\cdot$ Membrane fluidity $\cdot$ Cold adaptation

\section{Main}

To date, 1204 carotenoids of 722 source organisms have been identified and classified as $\mathrm{C}_{30}, \mathrm{C}_{40}$, and $\mathrm{C}_{50}$ carotenoids depending on the number of carbons in their carotene backbones (Yabuzaki 2017, 2020). They are involved as accessory pigments in photosynthesis (Holt et al. 2005), act as antioxidants (Mandelli et al. 2012; Miller et al. 1996), light protection pigments (Shahmohammadi et al. 1998), oxidative stress protection (Giani and Martínez-Espinosa 2020), and membrane stabilizers (Lazrak et al. 1987). As lipophilic compounds, carotenoids are located in the cellular membrane, but their orientation within the membrane can vary depending on their chemical structure and the thickness of the membrane (Gruszecki 2004; Milon et al. 1986). More than $95 \%$ of all natural carotenoids are based on the symmetric $\mathrm{C}_{40}$ phytoene backbone, and only a small number

Communicated by Erko Stackebrandt.

André Lipski

lipski@uni-bonn.de

1 Institute of Nutritional and Food Science, Food Microbiology and Hygiene, University of Bonn, Friedrich-Hirzebruch-Allee 7, 53115 Bonn, Germany of $\mathrm{C}_{30}$ and even fewer $\mathrm{C}_{50}$ carotenoids have been discovered (Tobias and Arnold 2006). Previous studies showed that carotenoids were able to lower the phase transition temperature of synthetic lipids (Subczynski et al. 1992, 1993), and this effect was dependent on the concentration of the pigment (Chaturvedi and Ramakrishna Kurup 1986; Strzałka and Gruszecki 1994; Subczynski et al. 1992). In accord with these observations, several authors argued that carotenoids might have a similar function in regulating membrane fluidity as sterols such as cholesterol or ergosterol in eukaryotic cells (Rohmer et al. 1979; Subczynski et al. 1992). Concerning the functions mentioned above, the involvement of carotenoids in bacterial cold adaptation was suspected especially for Arthrobacter agilis, Micrococcus roseus, and confirmed for Staphylococcus xylosus (Chattopadhyay et al. 1997; Fong et al. 2001; Seel et al. 2020; Strand et al. 1997).

The genus Arthrobacter, described by Conn and Dimmick (1947) and with an amendment by Busse (2016), is a predominant group of bacteria isolated from various sources such as soil, air, food, water, and plants, which has been found to produce a great variety of pigment hues, e.g., yellow, red, green, and blue (Sutthiwong et al. 2014). The species A. agilis and Arthrobacter bussei are known for the temperature-dependent pigmentation of the rare $\mathrm{C}_{50}$ carotenoid bacterioruberin and its glycosylated derivatives 
(Flegler et al. 2020; Fong et al. 2001). Fong et al. (2001) suspected that bacterioruberin is involved in adapting $A$. agilis strain MB813 to low-temperature growth conditions, which was isolated from Antarctic sea ice by Bowman et al. (1997). Therefore, we assumed that bacterioruberin in pinkpigmented Arthrobacter species has a similar function in regulating membrane fluidity as the carotenoid staphyloxanthin in $S$. xylosus, a species that also shows intense pigmentation at $10{ }^{\circ} \mathrm{C}$ growth temperature but no pigmentation at $30^{\circ} \mathrm{C}$ (Seel et al. 2020). This assumption is strengthened by the fact that, to date, all pink-pigmented Arthrobacter species have been isolated from low-temperature environments. Therefore, we hypothesized that bacterioruberin improves membrane properties under low-temperature conditions in A. agilis and A. bussei as model organisms. Using the methods employed in this work, we were able to relate changes in bacterioruberin content to changes in membrane fluidity by measuring the anisotropy of entire cells. Moreover, freeze-thaw stress tests demonstrate that the carotenoids also stabilize the cell membrane.

Comparative fatty acid profiles have already been established for strains A. agilis DSM $20550^{\mathrm{T}}$ and A. bussei DSM $109896^{\mathrm{T}}$ at 10 and $30^{\circ} \mathrm{C}$ growth temperature (Flegler et al. 2020). Both Arthrobacter species showed an adaptive response to low growth temperature, mainly based on the increase of unsaturated FAs for A. agilis and a shift from iso-branched to anteiso-branched fatty acid for A. bussei, respectively. The difference of the weighted average melting temperature $(\triangle \mathrm{WAMT})$ between cultures grown at 10 and $30{ }^{\circ} \mathrm{C}$ was calculated using the available percentage fatty acid abundance to derive the extent of FA-dependent temperature adaptation as described by Seel et al. (2020). In addition, we calculated $\triangle$ WAMT values from the fatty acid profiles published previously, based on the melting temperatures of free fatty acid given by Knothe and Dunn (2009). Both organisms showed a similar but moderate alteration in fatty acid composition resulting in a $\triangle$ WAMT of about $3{ }^{\circ} \mathrm{C}$ for A. agilis and $6.7^{\circ} \mathrm{C}$ for $A$. bussei. Thus, FA-dependent cold adaptation was lower in A. agilis compared to A. bussei.

\section{Increased bacterioruberin content alter membrane fluidity and support cold adaptation}

According to previous observations, the colonies of both Arthrobacter strains showed more pronounced pigmentation at low-temperature growth. The total carotenoid content of bacterioruberin and its glycosylated derivates was extracted with high-performance liquid chromatography (HPLC) as described by Kaiser et al. (2007) and Seel et al. (2020) and quantified as $\beta$-carotene equivalents using an external calibration curve. The quantitative HPLC analysis confirmed a significant increase in bacterioruberin at a growth temperature of $10{ }^{\circ} \mathrm{C}$ by about $60.4 \%$ in A. agilis and $264.1 \%$ in $A$. bussei. The total bacterioruberin content was higher in A. agilis compared to A. bussei if both strains were grown at $30^{\circ} \mathrm{C}$ (Fig. 1a). Anisotropy was measured to determine a correlation between the membrane fluidity and the bacterioruberin content. Sample preparation and membrane fluidity determination by trimethylammoniumdiphenylhexatriene (TMA-DPH) anisotropy measurement were performed as Seel et al. (2018) described. The results showed a similar behavior of the two strains with an evident influence of the higher bacterioruberin content at low growth temperatures (Fig. 1b). Growth at $30^{\circ} \mathrm{C}$ significantly reduced the bacterioruberin content of both Arthrobacter species, which showed an approximating phase transition, a

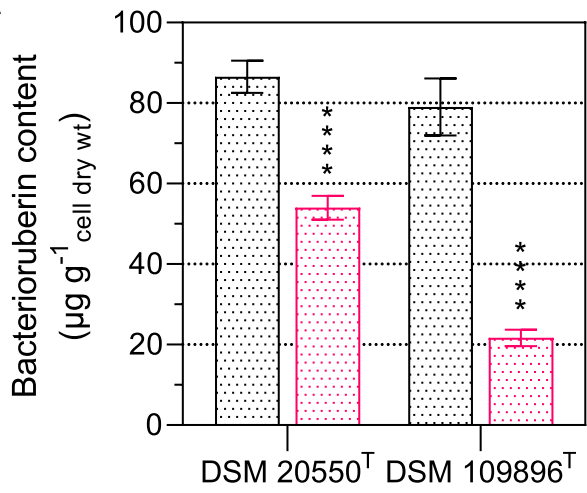

Fig. 1 Temperature-dependent bacterioruberin content and membrane fluidity. a Total bacterioruberin content of strains Arthrobacter agilis DSM $20550^{\mathrm{T}}$ and Arthrobacter bussei DSM $109896^{\mathrm{T}}$ grown at $10{ }^{\circ} \mathrm{C}$ (black) or $30{ }^{\circ} \mathrm{C}$ (red). b Membrane fluidity analyzed by TMA-DPH anisotropy of strains Arthrobacter agilis DSM $20550^{\mathrm{T}}$ b

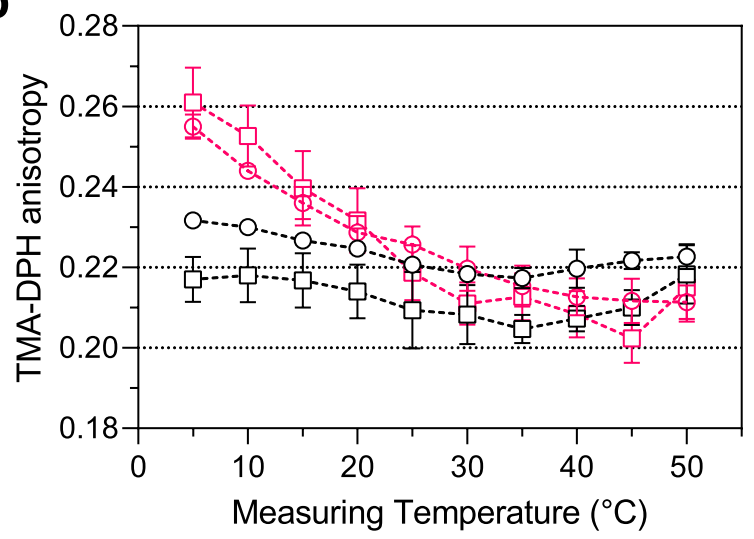

(squares) and Arthrobacter bussei DSM $109896^{\mathrm{T}}$ (circles) grown at $10{ }^{\circ} \mathrm{C}$ (black) and $30{ }^{\circ} \mathrm{C}$ (red). Values are means \pm standard deviation $(\mathbf{a}: n=6, \mathbf{b}: n=3)$. Asterisks represent $p$ values $\left({ }^{*} p<0.001\right.$, $* * p<0.0001, * * * p<0.00001, * * * * p<0.000001)$ compared to cultures grown at $10^{\circ} \mathrm{C}$ (colour figure online) 
indicated by the changed curve of measured anisotropy in a temperature range of $5-50{ }^{\circ} \mathrm{C}$. Characteristically, constant anisotropy values at the measurement range limits indicate the membranes' complete phase transition from the gellike solid-state (high anisotropy) to the liquid-crystalline fluid state (low anisotropy). Cultures grown at $10{ }^{\circ} \mathrm{C}$ with high bacterioruberin content showed no pronounced phase transitions in both species, evident from the slight increase of anisotropy with a decrease in temperature. However, $A$. bussei DSM $109896^{\mathrm{T}}$ with the lower bacterioruberin content at $10{ }^{\circ} \mathrm{C}$ exhibited higher average anisotropy values than A. agilis strain DSM $20550^{\mathrm{T}}$. Nevertheless, the membrane fluidity in both species was almost constant over the entire measured temperature range indicating a membrane fluidizing effect of the Arthrobacter carotenoids at low temperatures.

To confirm the effects of bacterioruberin content on membrane fluidity, we suppressed its synthesis for both Arthrobacter species by diphenylamine supplementation, according to Hammond and White (1970). Diphenylamine concentrations of 25,50 , and $75 \mu \mathrm{M}$ significantly reduced the bacterioruberin content in both tested species grown at $10{ }^{\circ} \mathrm{C}$ (data not shown). This approach, however, proved to be unsuitable because diphenylamine itself significantly alters membrane properties due to its lipophilic character, as already mentioned by Seel et al. (2020). Alternatively, to verify the effect of bacterioruberin on membrane fluidity, we suppressed bacterioruberin synthesis by adding sodium chloride $(\mathrm{NaCl})$, as achieved previously by Fong et al. (2001). A correlation between $\mathrm{NaCl}$ concentration and bacterioruberin synthesis was already reported for A. agilis and S. xylosus. We detected a similar correlation for A. agilis
DSM $20550^{\mathrm{T}}$ but not for A. bussei DSM $109896^{\mathrm{T}}$ (Fig. 2a). Supplementation of 2, 3, or $4 \%$ (wt/vol) $\mathrm{NaCl}$ significantly reduced the bacterioruberin content of $A$. agilis by about $64.2 \%, 70.9 \%$, or $72.4 \%$, respectively. This allows verifying the effect of bacterioruberin on the biophysical parameters of the cell membrane without changing the cultivation temperature. The decreased bacterioruberin content of A. agilis showed a clear impact on membrane fluidity (Fig. 2b). The anisotropy values showed a similar progression of the phase transition pattern between A. agilis cells grown at $30^{\circ} \mathrm{C}$ and cells supplemented with $4 \% \mathrm{NaCl}$ at $10{ }^{\circ} \mathrm{C}$. This resulted in a loss of membrane fluidity at low temperatures. On the other hand, A. bussei retained a higher membrane fluidity, which is related to the almost unchanged bacterioruberin content. These results confirmed that the measured effect on membrane fluidity was due to the cells' bacterioruberin content.

\section{Bacterioruberin content affects resistance to temperature stress}

It is unknown if the thermotropic phase transition by higher amounts of bacterioruberin finally impacts bacterial cell fitness under low-temperature conditions. In this study, using the term fitness as a quantitative attribute for the survival of an external stressor, the fitness of bacterial cells was tested by exposing them to freeze-thaw stress. Freeze-thaw stress resistance is a recognized indicator of cell membrane integrity and bacterial cell fitness (Carlquist et al. 2012; Flegler et al. 2021; Sleight et al. 2006). To confirm the correlation between bacterioruberin content and cell fitness, we achieved a reduced bacterioruberin content in both strains by cultivation at $30^{\circ} \mathrm{C}$. The freeze-thaw stress test

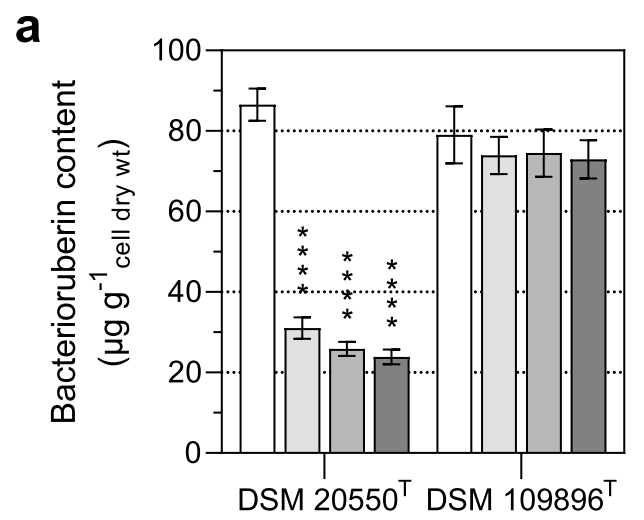

Fig. 2 Sodium chloride $(\mathrm{NaCl})$-dependent bacterioruberin content and membrane fluidity. a Total bacterioruberin content of strains Arthrobacter agilis DSM $20550^{\mathrm{T}}$ and Arthrobacter bussei DSM $109896^{\mathrm{T}}$ grown at $10{ }^{\circ} \mathrm{C}$ in tryptic soy broth supplemented with $0 \%$ (white), 2\% (light grey), 3\% (grey) or $4 \%$ (dark grey) (wt/vol) $\mathrm{NaCl}$. (b) Membrane fluidity analyzed by TMA-DPH anisotropy of strains b

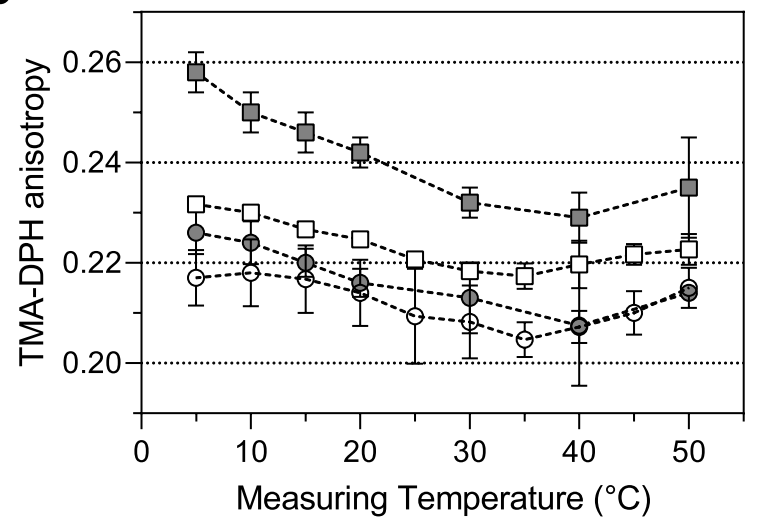

Arthrobacter agilis DSM $20550^{\mathrm{T}}$ (squares) and Arthrobacter bussei DSM $109896^{\mathrm{T}}$ (circles) grown at $10{ }^{\circ} \mathrm{C}$ in tryptic soy broth without $\mathrm{NaCl}$ (white) or with $4 \%$ (wt/vol) $\mathrm{NaCl}$ (dark grey). Values are means \pm standard deviation $(n=3)$. Asterisks represent $p$ values $(* p<0.001, * * p<0.0001, * * * p<0.00001, * * * * p<0.000001)$ compared to cultures grown at $10{ }^{\circ} \mathrm{C}$ 


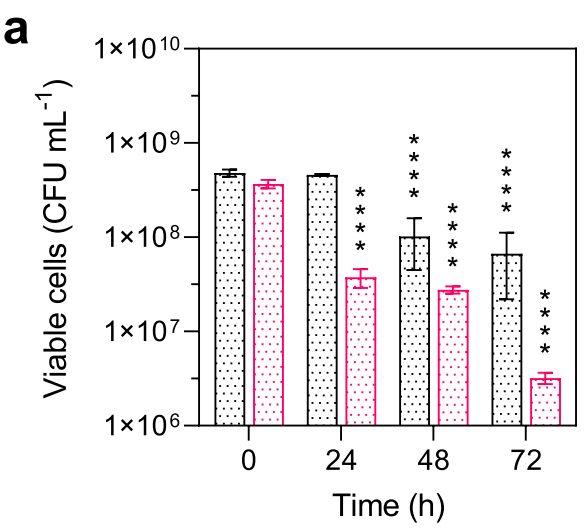

Fig. 3 Freeze-thaw stress test. Viable cell count of strains a Arthrobacter agilis DSM $20550^{\mathrm{T}}$ and b Arthrobacter bussei DSM $109896^{\mathrm{T}}$ grown at $10{ }^{\circ} \mathrm{C}$ (black) and $30{ }^{\circ} \mathrm{C}$ (red) in tryptic soy broth after one $(24 \mathrm{~h})$, two $(48 \mathrm{~h})$ and three $(72 \mathrm{~h})$ freeze-thaw cycles. Values

was performed according to Flegler et al. (2021). Indeed, freeze-thaw stress tests showed the positive effect of bacterioruberin on membrane integrity. A. agilis and A. bussei significantly reduced the number of viable cells grown at $30{ }^{\circ} \mathrm{C}$ compared to cultures grown at $10{ }^{\circ} \mathrm{C}$ (Fig. 3). Cells grown at $30{ }^{\circ} \mathrm{C}$ gradually decreased in the number of viable cells after each freeze-thaw cycle to a minimum of about

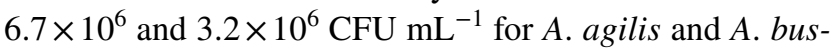
$s e i$, respectively, after the third freeze-thaw step. Almost no reduction in viable cells was measured for $A$. bussei grown at $10^{\circ} \mathrm{C}$. In contrast, $A$. agilis grown at $10{ }^{\circ} \mathrm{C}$ showed a slight decrease of viable cells after the second freeze-thaw step. These results confirmed the beneficial effect of an elevated bacterioruberin content on cell membrane integrity at $10{ }^{\circ} \mathrm{C}$ in both species.

\section{Conclusion}

This work reveals the beneficial effect of the bacterioruberin content of pink-pigmented Arthrobacter species on membrane fluidity under low-temperature conditions. These results strengthen that bacterioruberin is a fatty acid-independent mechanism for regulating membrane fluidity and represents an additional adaptive response to low growth temperatures with a beneficial impact on membrane integrity, as demonstrated by the increased resistance to freeze-thaw stress. The beneficial effect of this rare $\mathrm{C}_{50}$ carotenoid on cells of Arthrobacter species and other bacterioruberin-producing bacteria may in part explain the successful colonization of low-temperature environments by these organisms.

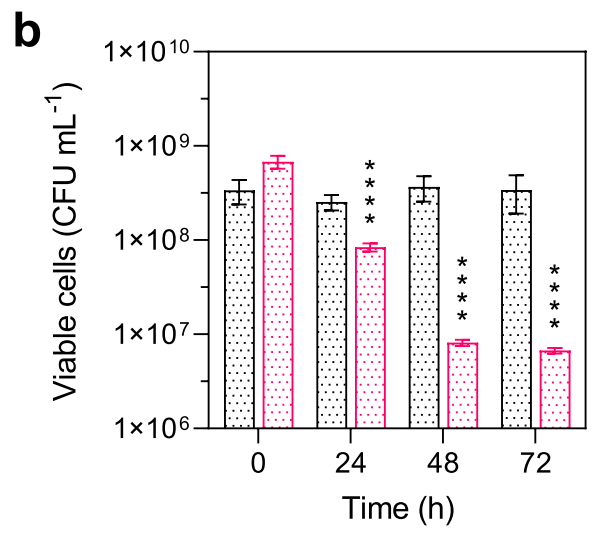

are means \pm standard deviation $(n=3)$. Asterisks represent $p$ values $(* p<0.001, * * p<0.0001, * * * p<0.00001, * * * * p<0.000001)$ compared to the initial cell count at $0 \mathrm{~h}$ (colour figure online)

\section{Materials and methods}

\section{Materials}

All chemical reagents and solvents were purchased from Alfa Aesar, Carl Roth, MilliporeSigma, Sigma-Aldrich, Thermo Fisher Scientific, and VWR. Solvents and water for analytics were of HPLC grade and used as received.

\section{Bacterial strains, culture media, and cultivation}

In this research, we examined two Arthrobacter strains. A. agilis DSM $20550^{\mathrm{T}}$ was isolated in 1981, and A. bussei DSM $109896^{\mathrm{T}}$ was isolated from cheese made of cow's milk in 2018. Both species belong to the "Pink Arthrobacter agilis group" within the "Arthrobacter agilis group" and showed a more intense pigmentation at low growth temperatures (Flegler et al. 2020).

All species were aerobically cultured in $100 \mathrm{~mL}$ tryptic soy broth (TSB). TSB contained $17.0 \mathrm{~g}$ peptone from casein $\mathrm{L}^{-1}, 3.0 \mathrm{~g}$ peptone from soy $\mathrm{L}^{-1}, 2.5 \mathrm{~g}$ D-glucose $\mathrm{L}^{-1}, 5.0 \mathrm{~g}$ sodium chloride $\mathrm{L}^{-1}$, and $2.5 \mathrm{~g}$ dipotassium hydrogen phosphate $\mathrm{L}^{-1}$ using $300 \mathrm{~mL}$ Erlenmeyer flasks. Growth in the TSB was documented by optical density (OD) at $625 \mathrm{~nm}$ with a GENESYS 30 visible spectrophotometer (Thermo Fisher Scientific, USA). Cultures were prepared in independent replicates, inoculated with $1 \%$ (vol/vol) of overnight culture, and incubated on an orbital shaker at 10 or $30{ }^{\circ} \mathrm{C}$ and $150 \mathrm{rpm}$ in the dark until late exponential phase $\left(\mathrm{OD}_{625 \mathrm{~nm}}=1-1.2\right)$. Cultures were harvested by centrifugation $(10,000 \times g$ for $10 \mathrm{~min})$ at growth temperature and washed thrice with sterile phosphate-buffered saline (PBS), which was adjusted to growth temperature, $\mathrm{pH}$ 7.4. Subsequently, this biomass was used for carotenoid analysis, membrane fluidity measurement, and freeze-thaw stress test. 
Colonies were cultivated on tryptic soy agar (TSA) containing $15.0 \mathrm{~g}$ peptone from casein $\mathrm{L}^{-1}, 5.0 \mathrm{~g}$ peptone from soy $\mathrm{L}^{-1}, 5.0 \mathrm{~g}$ sodium chloride $\mathrm{L}^{-1}$, and $15.0 \mathrm{~g}$ agar-agar $\mathrm{L}^{-1}$ at $30{ }^{\circ} \mathrm{C}$.

To determine colony-forming units (CFU) for the freeze-thaw stress test, serial dilutions were plated on TSA (90 mm Petri dish) using the exponential mode (ISO 4833-2, ISO 7218, and AOAC 977.27) of the easySpiral automatic plater (Interscience, France). After incubation for $48 \mathrm{~h}$ at $30{ }^{\circ} \mathrm{C}$, the $\mathrm{CFU}$ were counted for the corresponding dilution steps, and the weighted average of enumerated Arthrobacter sp. was given in $\mathrm{CFU} \mathrm{mL} \mathrm{m}^{-1}$. The results for the temperature stress test were presented as viable cells $\left(\mathrm{CFU} \mathrm{mL} \mathrm{mL}^{-1}\right)$.

\section{Statistical evaluation}

Statistical analysis was performed using Prism (version 9.2.0; GraphPad Software, United States). Mean values $(M)$ and standard deviations (SD) of $n$ (see legends) biological replicates were calculated for all experiments. Two-way ANOVA was performed with the recommended post hoc test $(\alpha=0.001)$. Data are presented as $M \pm \mathrm{SD} ; * p<0.001$, $* * p<0.0001, * * * p<0.00001, * * * * p<0.000001$.

Acknowledgements We are grateful to Bettina Becker (Food Microbiology and Hygiene, University of Bonn) for technical support. All experiments were performed at the University of Bonn.

Author contributions $\mathrm{AF}$ and $\mathrm{AL}$ designed the study. AF performed research, analyzed data, prepared figures, and wrote the manuscript. AL reviewed and edited the manuscript.

Funding Open Access funding enabled and organized by Projekt DEAL. Open Access funding enabled and organized by Projekt DEAL. The authors did not receive support from any organization for the submitted work.

\section{Declarations}

Conflict of interest The authors have no conflicts of interest to declare relevant to this article's content.

Data availability The data sets generated and analyzed during the current study are available on request from the corresponding author.

Open Access This article is licensed under a Creative Commons Attribution 4.0 International License, which permits use, sharing, adaptation, distribution and reproduction in any medium or format, as long as you give appropriate credit to the original author(s) and the source, provide a link to the Creative Commons licence, and indicate if changes were made. The images or other third party material in this article are included in the article's Creative Commons licence, unless indicated otherwise in a credit line to the material. If material is not included in the article's Creative Commons licence and your intended use is not permitted by statutory regulation or exceeds the permitted use, you will need to obtain permission directly from the copyright holder. To view a copy of this licence, visit http://creativecommons.org/licenses/by/4.0/.

\section{References}

Bowman JP, McCammon SA, Brown MV, Nichols DS, McMeekin TA (1997) Diversity and association of psychrophilic bacteria in Antarctic sea ice. Appl Environ Microbiol 63:3068-3078. https:// doi.org/10.1128/aem.63.8.3068-3078.1997

Busse H-J (2016) Review of the taxonomy of the genus Arthrobacter, emendation of the genus Arthrobacter sensu lato, proposal to reclassify selected species of the genus Arthrobacter in the novel genera Glutamicibacter gen. nov., Paeniglutamicibacter gen. nov., Pseudoglutamicibacter gen. nov., Paenarthrobacter gen. nov. and Pseudarthrobacter gen. nov., and emended description of Arthrobacter roseus. Int J Syst Evol Microbiol 66:9-37. https://doi.org/ 10.1099/ijsem.0.000702

Carlquist M, Fernandes RL, Helmark S, Heins A-L, Lundin L, Sørensen SJ, Gernaey KV, Lantz AE (2012) Physiological heterogeneities in microbial populations and implications for physical stress tolerance. Microb Cell Factories 11:94. https://doi.org/10. 1186/1475-2859-11-94

Chattopadhyay MK, Jagannadham MV, Vairamani M, Shivaji S (1997) Carotenoid pigments of an antarctic psychrotrophic bacterium Micrococcus roseus: temperature dependent biosynthesis, structure, and interaction with synthetic membranes. Biochem Biophys Res Commun 239:85-90. https://doi.org/10.1006/bbrc.1997.7433

Chaturvedi VK, Ramakrishna Kurup CK (1986) Interaction of lutein with phosphatidylcholine bilayers. Biochim Biophysic Acta Biomembr 860:286-292. https://doi.org/10.1016/00052736(86)90525-0

Conn HJ, Dimmick I (1947) Soil bacteria similar in morphology to Mycobacterium and Corynebacterium. J Bacteriol 54:291-303. https://doi.org/10.1128/jb.54.3.291-303.1947

Flegler A, Runzheimer K, Kombeitz V, Mänz AT, Heidler von Heilborn D, Etzbach L, Schieber A, Hölzl G, Hüttel B, Woehle C, Lipski A (2020) Arthrobacter bussei sp. nov., a pink-coloured organism isolated from cheese made of cow's milk. Int J Syst Evol Microbiol 70:3027-3036. https://doi.org/10.1099/ijsem.0. 004125

Flegler A, Kombeitz V, Lipski A (2021) Menaquinone-mediated regulation of membrane fluidity is relevant for fitness of Listeria monocytogenes. Arch Microbiol 203:3353-3360. https://doi.org/ 10.1007/s00203-021-02322-6

Fong NJC, Burgess ML, Barrow KD, Glenn DR (2001) Carotenoid accumulation in the psychrotrophic bacterium Arthrobacter agilis in response to thermal and salt stress. Appl Microbiol Biotechnol 56:750-756. https://doi.org/10.1007/s002530100739

Giani M, Martínez-Espinosa RM (2020) Carotenoids as a protection mechanism against oxidative stress in Haloferax mediterranei. Antioxidants 9:1060. https://doi.org/10.3390/antiox9111060

Gruszecki WI (2004) Carotenoid Orientation: Role in membrane stabilization. In: Krinsky NI, Mayne ST, Sies H (eds) Carotenoids in health and disease, 1st edn. CRC Press, Boca Raton, pp 151-164

Hammond RK, White DC (1970) Inhibition of vitamin $\mathrm{K}_{2}$ and carotenoid synthesis in Staphylococcus aureus by diphenylamine. J Bacteriol 103:611-615

Holt NE, Zigmantas D, Valkunas L, Li X-P, Niyogi KK, Fleming GR (2005) Carotenoid cation formation and the regulation of photosynthetic light harvesting. Science 307:433-436. https://doi.org/ 10.1126/science. 1105833

Kaiser P, Surmann P, Vallentin G, Fuhrmann H (2007) A small-scale method for quantitation of carotenoids in bacteria and yeasts. $J$ Microbiol Methods 70:142-149. https://doi.org/10.1016/j.mimet. 2007.04.004

Knothe G, Dunn RO (2009) A comprehensive evaluation of the melting points of fatty acids and esters determined by differential scanning 
calorimetry. J Am Oil Chem Soc 86:843-856. https://doi.org/10. 1007/s11746-009-1423-2

Lazrak T, Milon A, Wolff G, Albrecht A-M, Miehé M, Ourisson G, Nakatani Y (1987) Comparison of the effects of inserted $\mathrm{C}_{40^{-}}$ and $\mathrm{C}_{50}$-terminally dihydroxylated carotenoids on the mechanical properties of various phospholipid vesicles. Biochim Biophysic Acta Biomembr 903:132-141. https://doi.org/10.1016/00052736(87)90163-5

Mandelli F, Miranda VS, Rodrigues E, Mercadante AZ (2012) Identification of carotenoids with high antioxidant capacity produced by extremophile microorganisms. World J Microbiol Biotechnol 28:1781-1790. https://doi.org/10.1007/s11274-011-0993-y

Miller NJ, Sampson J, Candeias LP, Bramley PM, Rice-Evans CA (1996) Antioxidant activities of carotenes and xanthophylls. FEBS Lett 384:240-242. https://doi.org/10.1016/0014-5793(96)00323-7

Milon A, Wolff G, Ourisson G, Nakatani Y (1986) Organization of carotenoid-phospholipid bilayer systems. Incorporation of zeaxanthin, astaxanthin, and their $\mathrm{C}_{50}$ homologues into dimyristoylphosphatidylcholine vesicles. Helv Chim Acta 69:12-24. https://doi. org/10.1002/hlca.19860690104

Rohmer M, Bouvier P, Ourisson G (1979) Molecular evolution of biomembranes: structural equivalents and phylogenetic precursors of sterols. Proc Natl Acad Sci USA 76:847-851. https://doi. org/10.1073/pnas.76.2.847

Seel W, Flegler A, Zunabovic-Pichler M, Lipski A (2018) Increased isoprenoid quinone concentration modulates membrane fluidity in Listeria monocytogenes at low growth temperatures. J Bacteriol 200:e00148-18. https://doi.org/10.1128/JB.00148-18

Seel W, Baust D, Sons D, Albers M, Etzbach L, Fuss J, Lipski A (2020) Carotenoids are used as regulators for membrane fluidity by Staphylococcus xylosus. Sci Rep 10:330. https://doi.org/10. 1038/s41598-019-57006-5

Shahmohammadi HR, Asgarani E, Terato H, Saito T, Ohyama Y, Gekko K, Yamamoto O, Ide H (1998) Protective roles of bacterioruberin and intracellular $\mathrm{KCl}$ in the resistance of Halobacterium salinarium against DNA-damaging agents. J Radiat Res 39:251-262. https://doi.org/10.1269/jrr.39.251

Sleight SC, Wigginton NS, Lenski RE (2006) Increased susceptibility to repeated freeze-thaw cycles in Escherichia coli following longterm evolution in a benign environment. BMC Evol Biol 6:104. https://doi.org/10.1186/1471-2148-6-104
Strand A, Shivaji S, Liaaen-Jensen S (1997) Bacterial carotenoids 55. $\mathrm{C}_{50}$-carotenoids $25 . \dagger$ revised structures of carotenoids associated with membranes in psychrotrophic Micrococcus roseus. Biochem Syst Ecol 25:547-552. https://doi.org/10.1016/S0305-1978(97) 00039-2

Strzałka K, Gruszecki WI (1994) Effect of $\beta$-carotene on structural and dynamic properties of model phosphatidylcholine membranes. I. An EPR spin label study. Biochim Biophysic Acta Biomembr 1194:138-142. https://doi.org/10.1016/0005-2736(94)90212-7

Subczynski WK, Markowska E, Gruszecki WI, Sielewiesiuk J (1992) Effects of polar carotenoids on dimyristoylphosphatidylcholine membranes: a spin-label study. Biochim Biophysic Acta Biomembr 1105:97-108. https://doi.org/10.1016/0005-2736(92) 90167-K

Subczynski WK, Markowska E, Sielewiesiuk J (1993) Spin-label studies on phosphatidylcholine-polar carotenoid membranes: effects of alkyl-chain length and unsaturation. Biochim Biophysic Acta Biomembr 1150:173-181. https://doi.org/10.1016/0005-2736(93) 90087-G

Sutthiwong N, Fouillaud M, Valla A, Caro Y, Dufossé L (2014) Bacteria belonging to the extremely versatile genus Arthrobacter as novel source of natural pigments with extended hue range. Food Res Int 65:156-162. https://doi.org/10.1016/j.foodres.2014.06.024

Tobias AV, Arnold FH (2006) Biosynthesis of novel carotenoid families based on unnatural carbon backbones: a model for diversification of natural product pathways. Biochim Biophys Acta Mol Cell Biol Lipids 1761:235-246. https://doi.org/10.1016/j.bbalip. 2006.01.003

Yabuzaki J (2017) Carotenoids database: structures, chemical fingerprints and distribution among organisms. Database 2017:bax004. https://doi.org/10.1093/database/bax004

Yabuzaki J (2020) Carotenoid database. http://carotenoiddb.jp/index. html. Accessed 18 Nov 2021

Publisher's Note Springer Nature remains neutral with regard to jurisdictional claims in published maps and institutional affiliations. 